\begin{tabular}{|c|c|c|}
\hline Dinamika Journal, Vol. 1 No. 4, 2019 \\
ISSN ONLINE : 2686-2158
\end{tabular}

\title{
PENYEDIAAN PRASARANA AIR BERSIH DI DESA BINANGUN KECAMATAN MREBET KABUPATEN PURBALINGGA
}

\author{
Gandjar Pamudji ${ }^{1, *}$, Yanuar Haryanto ${ }^{1,2}$, Arnie Widyaningrum ${ }^{1}$, Nor Intang Setyo \\ Hermanto $^{1}$, Agus Maryoto ${ }^{1}$ \\ ${ }^{1}$ Jurusan Teknik Sipil, Fakultas Teknik, Universitas Jenderal Soedirman, Indonesia \\ ${ }^{2}$ Department of Civil Engineering, Collegae Engineering, National Cheng Kung University, \\ Taiwan \\ *Corresponding author: gandjar.pamudji@unsoed.ac.id
}

Received 30 November 2019; Accepted 12 December 2019; Available online 19 December 2019

\begin{abstract}
Abstrak
Khalayak mitra dalam Pengabdian Kepada Masyarakat skim KKN Tematik adalah Desa Binangun, Kecamatan Mrebet Kabupaten Purbalingga, Jawa Tengah. Permasalahan yang harus diselesaikan adalah kesulitan/kekuerangan ketersediaan air bersih pada saat musim kemarau. Penyelesaian masalah ini dilakukan menjadi dua tahap yaitu tahap pertama melakukan pencarian sumber mata air di pegunungan Slamet serta membuat penampungan air bersih disekitar lokasi sumber mata air. Tahap kedua adalah menyalurkan air dari penampungan air bersih disekitar lokasi sumber mata air ke pamsimas dusun IV desa Binangun Kecamatan Mrebet Kabupaten Purbalingga. Melalui kegiatan KKN Tematik dan bantuan dana dari pemerintah setempat maka pendistribusian air dari sumber mata air pegunungan telah dapat dialiri hingga penampungan PAMSIMAS dusun IV desa Binangun.
\end{abstract}

Kata-kata kunci : KKN Tematik, desa Binangun, dusun IV, PAMSIMAS

\begin{abstract}
Audience partners in Community Service for Thematic KKN scheme are Binangun village, Mrebet sub-district, Purbalingga district, Central Java. The problem that must be resolved is the difficulty/lack of availability of clean water during the dry season. This problem resolving was carried out into two stages, namely the first stage of searching spring sources in the Slamet mountains and building a reservoir of clean water around the location of the spring. The second stage is channeling water from the reservoir around the location of the springs to pamsimas in sub-village-IV Binangun village, Mrebet sub-district, Purbalingga district. Through the Thematic and funding assistance from the local government, the distribution of water from mountain springs can be drain to the PAMSIMAS storage in sub village-IV, Binangun village.
\end{abstract}

Keywords: KKN Tematik, Binangun village, sub village IV, PAMSIMAS 


\section{PENDAHULUAN}

Umumnya kedalaman air tanah sangat dipengaruhi oleh kondisi topografi, geografis, faktor musim dan faktor ketebalan tanah. Pada daerah yang tergolong dataran rendah, air tanah lebih mudah ditemukan atau dapat dikatakan bahwa air tanah tersebut termasuk jenis air tanah dangkal. Pada dataran tinggi, untuk memperoleh air tanah terbilang cukup sulit terutama untuk melakukan penggalian. Biasanya masyarakat yang tinggal di dataran tinggi lebih memanfaatkan sumber air lain seperti hulu sungai, air hujan atau mata air lainnya.

Saat musim hujan volume air tanah akan meningkat karena banyaknya air hujan yang masuk ke dalam pori-pori tanah dan tertampung di dalam lapisan kedap air bawah tanah. Sedangkan saat musim kemarau, volume air tanah tidak terlalu tinggi akibat berkurangnya serta tidak adanya tambahan air yang berasal dari hujan. Tidak heran jika di beberapa tempat sumur-sumur akan mengalami kekeringan saat musim kemarau panjang sedang melanda.

Beberapa daerah di Indonesia, diantaranya daerah yang terdiri dari endapan pasir lepas. hasil erupsi gunung api, mengalami kesulitan pasokan air untuk keperluan sehari-hari. Endapan pasir lepas secara umum memiliki karakteristik drainase yang tinggi sehingga air dapat dengan mudah berinfiltrasi ke bawah permukaan (Holtz \& Kovacs, 1981).

Dusun IV desa Binangun secara administratif termasuk ke dalam wilayah kecamatan Mrebet, kabupaten Purbalingga mengalami permasalahan kesulitan pasokan air untuk keperluaan sehari-hari masyarakat terutama pada musim kemarau. Desa ini berjarak sekitar 7 $\mathrm{km}$ dari ibu kota kecamatan yang dapat ditempuh dengan kendaraan sekitar 15 menit. Sedangkan jarak dari kota kabupaten sekitar $15 \mathrm{~km}$ dan dapat ditempuh dengan kendaraan kurang lebih 20 menit. Desa Binangun yang terdiri dari 4 dusun dan 19 RT merupakan daerah yang termasuk dataran tinggi dimana batas wilayah desa meliputi: Desa Pengalusan di sebelah utara, desa Bumisari di sebelah selatan, Perhutani di sebelah barat dan desa Cipaku di sebelah timur. Koefisien kelulusan air material penyusunnya yang relatif tinggi menyebabkan air hujan yang jatuh langsung meresap ke bawah permukaan.

Wilayah barat desa tersebut merupakan kawasan hutan yang berada dikawasan vulkanik gunung Slamet, yang merupakan kantong-kantong raksasa penyimpan air (khususnya air tanah) yang ditandai kawasan bercurah hujan tinggi. Dengan potensi sumber air yang belum jelas diketahui dan terukur, kegiatan ini dilakukan dalam rangka mencari sumber mata air yang memiliki debit yang cukup dan didistribusikan ke PAMSIMAS untuk memenuhi kebutuhan masyarakat Desa Binangun terutama Dusun IV. Seiring dengan keinginan peran Fakultas Teknik Unsoed untuk pembangunan di Purbalingga, pembangunan distribusi air dari sumber mata air berikutnya oleh tim KKN Tematik akan terfokus di desa Binangun, kecamatan Mrebet, Kabupaten Purbalingga.

\section{METODE PELAKSANAAN}

Tim PKM bersama dengan mahasiswa KKN berintegrasi menyusun persiapan untuk pelaksanaan KKN dan PKM. Diawali dengan survei Tim PKM dan Mahasiswa dari berbagai Fakultas ke lokasi KKN dalam rangka koordinasi dengan apparat dan warga desa. kegiatan ini bertujuan untuk menyalurkan air dari bak penampungan ke Pamsimas dusun IV desa Binangun, Kecamatan Mrebet, Kabupaten Purbalingga. Kegiatan Pengabdian kepada masyarakat ini dilaksanakan di desa Binangun dusun IV kecamatan Mrebet Purbalingga. Adapun langkah-langkah yang dilakukan untuk mencapai tujuan ini adalah :

1. Pembekalan kepada calon mahasiswa KKN Tematik untuk menyamakan persepsi tentang program utama KKN dan pemberian pengetahuan pendistribusian saluran air bersih serta perhitungan kebutuhan bahan dan tenaga pembuatan jaringan air bersih.

2. Sosialisasi air bersih dan pendistribusian pipa air bersih. 
3. Perancangan jalur pendistribusian pipa air bersih dan pemasangan pipa air bersih yang mengacu pada Departemen Kimpraswil (2003) dan Direktorat Jenderal Cipta Karya (2007).

\section{HASIL DAN PEMBAHASAN}

\subsection{Pembekalan}

Pembekalan KKN tematik (Gambarv 3) dilaksanakan di Kampus Fakultas Teknik Universitas Jenderal Soedirman dengan tujuan memberikan pemahaman kepada mahasiswa sebelum diterjunkan dapat menghitung kebutuhan biaya pelaksanaan jaringan distribusi air. Kegiatan ini diikuti oleh peserta KKN Tematik 2019 dan unsur pimpinan desa dalam hal ini adalah kepala Dusun IV dan Kepala Urusan Pembangunan Desa Binangun.
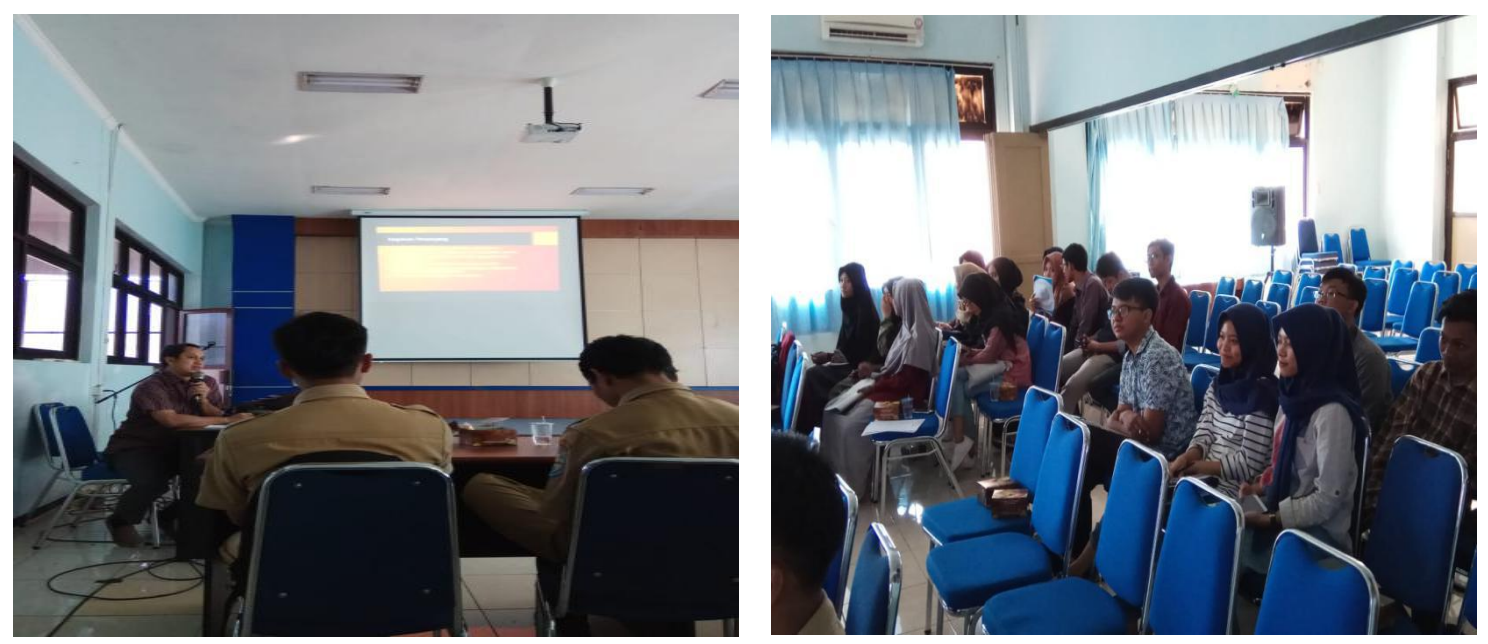

Gambar 3. Pembekalan KKN Tematik 2019

\subsection{Sosialisasi Syarat dan Standar Kualitas Air Minum di Perairan Umum}

Air bersih adalah salah satu jenis sumberdaya berbasis air yang bermutu baik dan biasa dimanfaatkan oleh manusia untuk dikonsumsi atau dalam melakukan aktivitas mereka seharihari termasuk diantaranya adalah sanitasi (Anonim, 2017).

Dalam penggunaannya, air bersih sebagai unsur penting dalam kehidupan, berangsurangsur mengalami penurunan secara kuantitatif dan kualitatif. Semakin meningkatnya populasi, semakin besar pula kebutuhan akan air minum. Sehingga ketersediaan air bersih pun semakin berkurang.

Untuk konsumsi air minum menurut departemen kesehatan, syarat-syarat air minum adalah tidak berasa, tidak berbau, tidak berwarna, dan tidak mengandung logam berat. Walaupun air dari sumber alam dapat diminum oleh manusia, terdapat risiko bahwa air ini telah tercemar oleh bakteri (misalnya Escherichia coli) atau zat-zat berbahaya. Walaupun bakteri dapat dibunuh dengan memasak air hingga $100^{\circ} \mathrm{C}$, banyak zat berbahaya, terutama logam, tidak dapat dihilangkan dengan cara ini (Anonim, 2010).

Syarat dan standar kualitas air minum disampaikan pada saat kegiatan sosialisasi yang dilaksanakan di balai Desa Binangun yang diikuti oleh warga Desa Binangun, terkhusus warga Dusun IV. Tujuan dari kegiatan ini adalah Untuk memberikan pengetahuan dan informasi kepada masyarakat Desa Binangun terutama warga Dusun IV tentang metode pengukuran debit air juga syarat dan standar terhadap kualitas air minum yang ada di perairan umum. 
Capaian yang ditargetkan dalam kegiatan ini adalah kegiatan sosialisasi berjalan dinamis dua arah. Warga bahkan perangkat desa dan juga karang taruna begitu antusias terhadap sosialisasi yang diberikan oleh pemateri dari pihak PDAM Kab. Purbalingga seperti dapat dilihat pada Gambar 4.. Sesi diskusi dimanfaatkan dengan baik oleh peserta untuk mengetahui lebih banyak terkait hubungannya dengan pendistribusian air bersih di Desa Binangun.

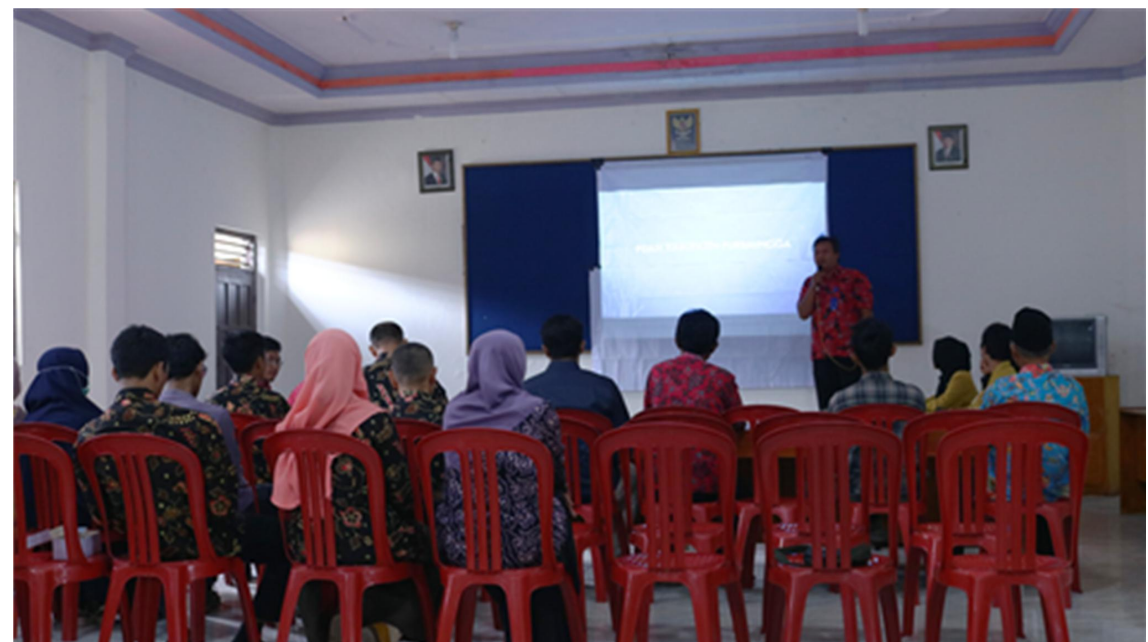

Gambar 4. Sosialisasi Pengukuran Debit Air serta Sosialisasi Syarat dan Standar Kualitas Air Minum di Perairan Umum

Dalam kegiatan sosialisasi ini, belum menemukan kendala yang berarti, hanya keterlambatan dimulainya kegiatan sosialisasi dikarenakan harus menunggu kedatangan dari peserta sosialisasi, yakni masyarakat Desa Binangun. Yang menjadi pendorong dalam kegiatan ini adalah masyarakat, perangkat desa dan juga lembaga karang taruna memberikan respons yang positif terkait adanya kegiatan sosialisasi, yang dapat dijadikan wadah oleh mereka untuk menambah wawasan terkait nantinya pengelolaan air bersih. Rekomendasi yang kami berikan kepada desa, terutama perangkat desa dan karang taruna untuk ke depannya bisa menjadi pemeran penting dalam pengelolaan air bersih dengan menerapkan ilmu yang didapat bila air sudah terdistribusi dengan baik ke Desa Binangun, agar dapat dimanfaatkan oleh seluruh masyarakat secara adil dan merata.

\subsection{Pembangunan Distribusi Air Bersih}

Menurut Direktorat Jenderal Cipta Karya (2007), Sistem Penyedia Air Minum (SPAM) komunal Sumur Air Tanah Dalam (STAD) adalah sistem penyediaan air minum yang menggunakan air tanah dalam sebagai sumber air baku untuk air minum. Konstruksi sumur dalam terdiri dari:

1. Pipa jambang (casing):

a. Bahan pipa baja atau bahan lain seperti PVC, fiberglass dan GIP atau sejenis dengan spesifikasi mampu untuk menahan tekanan dari dinding atau batuan.

b. Pipa jambang dibuat muncul minimal $50 \mathrm{~cm}$ di atas lantai beton pengaman

c. Diameter pipa jambang minimal 4 inci.

2. Pipa buta

Bahan untuk pipa buta adalah pipa baja atau bahan lain seperti PVC, fiberglass dan GIP atau yang sejenis dengan spesifikasi mampu untuk menahan tekanan dari dinding tanah atau batuan.

3. Pipa saringan 
a. Tipe saringan atau screen adalah "Wire Wound Continuous Slot" on "Rod Base" yaitu berbentuk kawat yang melingkar pada penyangga (rod base) dengan jarak kawat yang sama.

b. Syarat teknis pipa saringan:

1) Bukaan (25-40)\% tergantung jenis material pada akuifer.

2) Jumlah rod base 20-36 buah kawat penyangga.

3) Tebal kawat yang umum dipakai berkisar antara $(2-2,5) \mathrm{mm}$.

c. Pipa saringan dapat dibuat dari jenis PVC, fiberglass dan GIP yang dibuat oleh pabrik sesuai dengan persyaratan yang ditentukan.

Pembangunan distribusi air bersih sepanjang kurang lebih $3 \mathrm{~km}$ dari sumber mata air ke penampungan air Dusun IV seperti dijelaskan pada Gambar 5. Panjang jaringan pipa distribusi air bersih yang dilaksanakan dalam kegiatan KKN Tematik bersama warga dibiayai oleh Hibah KKN Tematik 2019 adalah sepanjang kurang lebih 1,48 KM atau separuh dari kebutuhan. Sedangkan sisanya akan menggunakan dana bantuan dari pemda kabupaten Purbalingga melalui Desa Binangun dan dibangun oleh warga Desa Binangun. Kegiatan ini dilaksanakan oleh mahasiswa KKN Tematik Unsoed tahun 2019 bersama Warga Dusun IV Desa Binangun.

Tujuan yang dicapai kegiatan ini adalah membangun sistem pendistribusian air dari penampungan yang telah dibangun melalui kegiatan KKN Tematik 2018 (Gambar 6). Kegiatan pendistribusian air bersih ini telah menghasilkan sistem pendistribusian air menggunakan kombinasi pipa PVC dan HDPE sejauh 1,48 km dari sumber air. Sejumlah warga Dusun IV juga antusias ikut serta dengan bergotong royong mulai dari pembabatan lahan hingga pemasangan pipa. Kendala yang dihadapi selama pendistribusian air bersih ini antara lain:

1. Proses perencanaan trase pipa berlangsung cukup lama karena medan yang sulit dan masuk ke dalam hutan sehingga membutuhkan survei yang harus dilakukan berulang kali untuk memastikan trase pipa yang telah dibuat.

2. Masalah perizinan kepada pihak Perhutani yang membutuhkan waktu cukup lama sehingga proses pemasangan pipa tertunda.

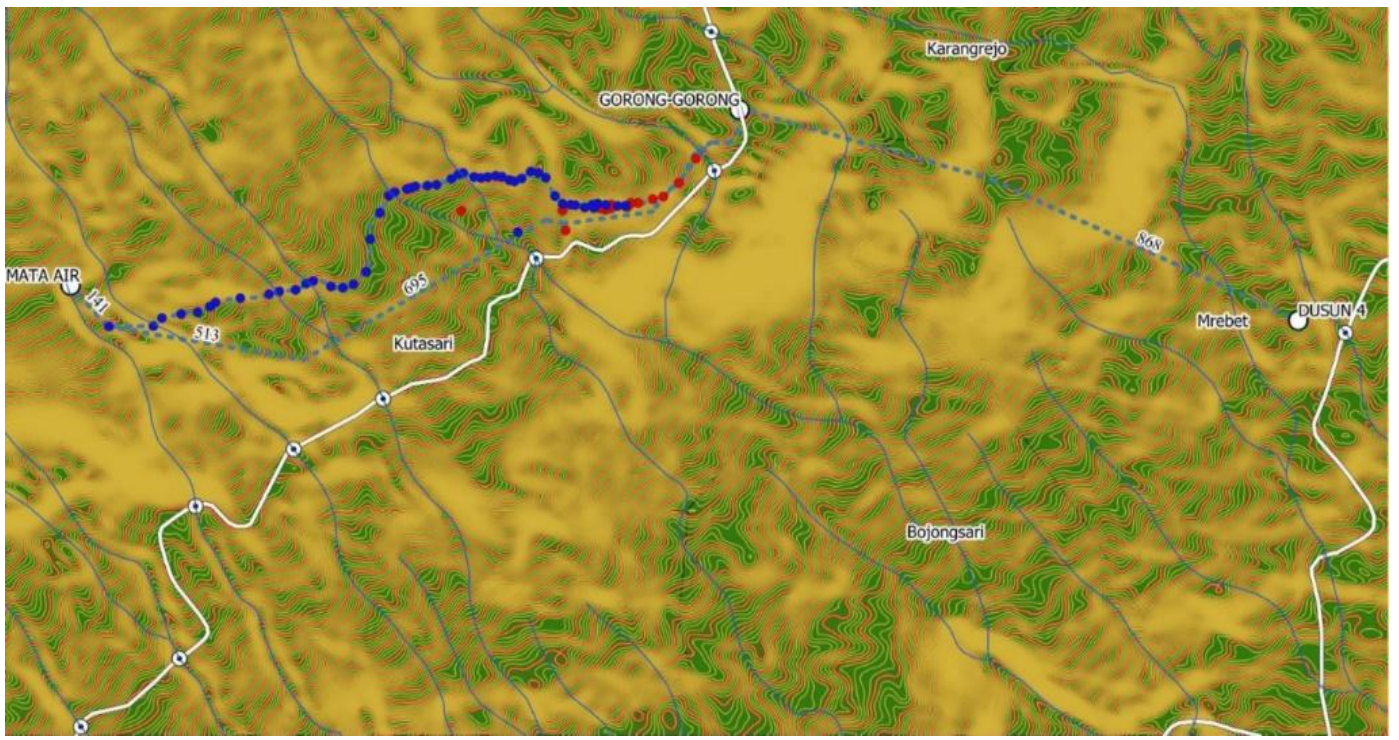

Gambar 5. Rencana pembangunan jaringan pipa distribusi air bersih. 

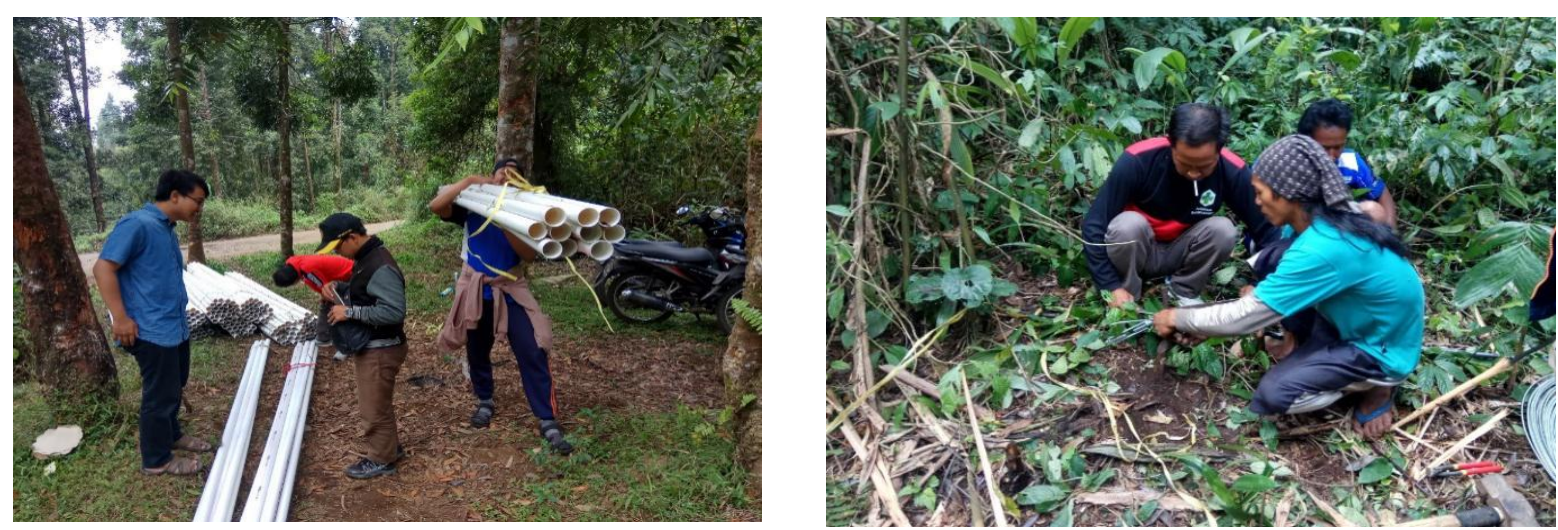

Gambar 6. Pemasangan Pipa Distribusi Air Bersih dari Penampungan mata air

\section{KESIMPULAN}

Berdasarkan pelaksanaan Kuliah Kerja Nyata Tematik 2019 di Desa Binangun Kecamatan Mrebet Kabupaten Purbalingga, dapat disimpulkan sebagai berikut:

1. Program kerja KKN Tematik BLU berupa fisik dan nonfisik dapat terlaksana dengan baik dan mendapatkan bantuan dari masyarakat tenaga maupun moril serta bantuan dari pemerintah daerah sehingga distribusi air dapat tersalurkan hingga Pamsimas.

2. Program kerja KKN Tematik BLU di Desa Binangun mendapat sambutan yang baik dari masyarakat setempat yang diwujudkan dengan memberikan dukungan moril maupun materiil demi kelancaran pelaksanaan kegiatan.

3. Kepala Desa beserta Perangkat Desa Binangun tokoh masyarakat, serta para pemuda mempunyai hubungan yang baik, loyalitas, dedikasi yang tinggi demi membangun Desa Binangun.

\section{UCAPAN TERIMA KASIH}

Terima kasih penulis sampaikan kepada LPPM Universitas Jemdral Soedirman yang telah memberikan dukungan dan memfasilitasi sehingga kegiatan KKN Tematik TA 20182019 ini dapat terlaksana. Selain itu tak lupa kami sampaikan juga kepada warga desa Binangun khususnya warga dusun IV yang telah membantuk kegiatan ini sehingga kebutuhan air bersih saat ini bisa terwujud dan dirasakan manfaatnya bagi warga dusun IV desa Binangun.

\section{DAFTAR PUSTAKA}

Anonim. 2010. Peraturan Menteri Kesehatan Republik Indonesia Nomor 492/MENKES/PER/IV/2010. Persyaratan Kualitas Air Minum.

Anonim. 2017. Peraturan Menteri Kesehatan Republik Indonesia Nomor 32 Tahun 2017. Standar Baku Mutu Kesehatan Lingkungan Dan Persyaratan Kesehatan Air Untuk Keperluan Higiene Sanitasi, Kolam Renang, Solus Per Aqua, Dan Pemandian Umum.

Departemen Kimpraswil. 2003. Petunjuk Praktis Pembangunan Prasarana dan Sarana Sistem Penyediaan Air Bersih Perdesaan. Kementerian Pekerjaan Umum, Jakarta.

Direktorat Jenderal Cipta Karya. 2007. Juknis Pelaksanaan Prasarana Air Minum Sederhana. Kementerian Pekerjaan Umum, Jakarta.

Holtz, R.D. \& Kovacs, W.D. 1981. An Introduction to Geotechnical Engineering. Prentice-Hall. 